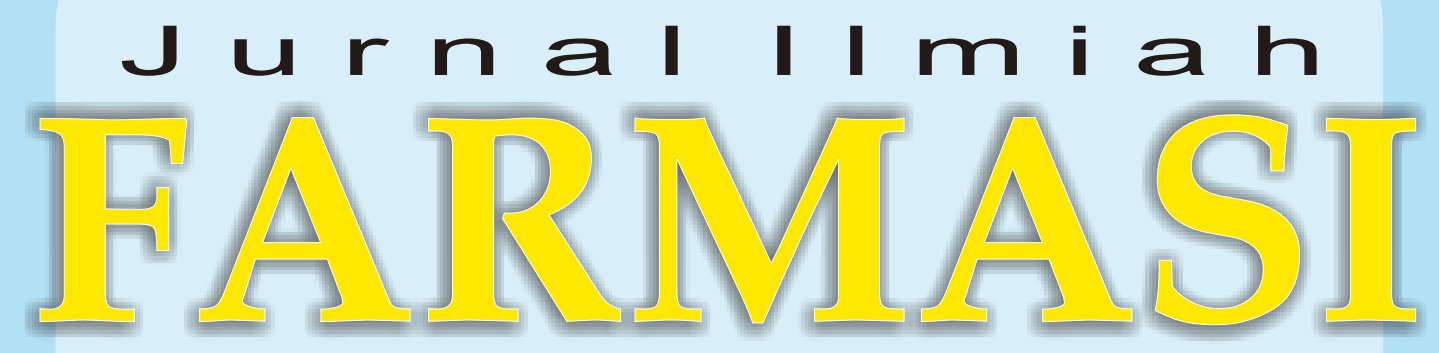

(Scientific Journal of Pharmacy) 
JURNAL ILMIAH FARMASI

(SCIENTIFIC JOURNAL OF PHARMACY)

PIMPINAN UMUM/ PENANGGUNG JAWAB

Dekan Fakultas Matematika dan Ilmu Pengetahuan Alam

Universitas Islam Indonesia

WAKIL PIMPINAN UMUM/ WAKIL PENANGGUNG JAWAB

Ketua Jurusan Farmasi FMIPA UII

\section{MITRA BESTARI}

1. Prof. Dr. Wiryatun Lestariana, Apt

2. Prof. Dr. Zullies Ikawati, Apt

3. Prof. Dr. Sudibyo Martono, Apt

4. Dr. Tedjo Yuwono, Apt

5. Prof. Dr. Dachriyanus, Apt

6. Prof. dr. Iwan Dwiprahasto, MMedSc, PhD

7. Prof. Dr. Lukman Hakim M.Sc., Apt

8. Prof. Dr. Achmad Fudholi, DEA, Apt

9. Prof. Dr. Ibnu Gholib Gandjar, DEA., Apt

\begin{tabular}{ll} 
& \multicolumn{1}{c}{ DEWAN EDITOR } \\
Ketua & : Saepudin, M.Si., Apt \\
Sekretaris & : Rochmy Istikharah, M.Sc., Apt. \\
Anggota & : Vitarani Dwi Ananda Ningrum, M.Si., Apt \\
& Okti R. Mafruhah, MSc., Apt \\
& Dimas Adhi Pradana, MSc., Apt. \\
& Fithria DA. Suryanegara, MSc., Apt. \\
& Ari Wibowo, S.Farm., Apt \\
& Arba Pramudita Ramadani, MSc., Apt. \\
& Oktavia Indrati, S.Farm., Apt.
\end{tabular}

Penerbit

Jurusan Farmasi Fakultas Matematika dan IImu Pengetahuan Alam Universitas Islam Indonesia

Alamat Penerbit Jurusan Farmasi FMIPA UII

Jl. Kaliurang Km. 14,4 Yogyakarta 55584

Telp. (0274) 896439 ext. 3047

Email: jif@uii.ac.id 


\title{
PENINGKATAN DISOLUSI FUROSEMIDA DENGAN PEMBENTUKAN KOMPLEKS INKLUSI MELALUI KOPRESIPITASI MENGGUNAKAN $\beta$ - SIKLODEKSTRIN
}

\author{
Nurul Ainah*), Yandi Syukri*), M. Hatta Wibowo*) \\ *) Jurusan Farmasi, FMIPA UII
}

\begin{abstract}
Furosemide is a diuretic drug, which is insoluble in water. Due to this condition, it is needed a way to increase the dissolution rate with forming of inclusion complex in copresipitation system which produce as solid dispersion product using $\beta$-cyclodextrin carrier. The copresipitation system was made up of $1: 0,5 ; 1: 1 ; 1: 1,5$ and $1: 2$ variation concentration of furosemide- $\beta$ cyclodextrin. The characteristic forming of inclusion complex in solid dispersion system was evaluated by infrared analysis and then followed by HyperChem molecular model analysis. The dissolution test was done in order to see the increasing of dissolution rate and this test is used buffer phosphate $\mathrm{pH} 5,8$ as the medium with rotation speed $100 \mathrm{rpm}$ at $37 \pm 0,5^{\circ} \mathrm{C}$ for 60 minutes. The amount of dissoluted furosemide was then analyzed by spectrophotometric test. The dissolution parameter with Dissolution Efficiency (DE) is conducted in 10, 30, and 60 minutes. The data were analyzed with Two Way ANOVA at $p<0.05$ then continued with $t$-test. The result of this experiment shows that the solid dispersion of furosemide- $\beta$-cyclodextrin with ratio $1: 1,5$ and $1: 2$ have the highest percentage of dissolution. The increasing of dissolution of inclusion complex in copresipitation system using $\beta$-cyclodextrin $(1: 1,5)$ is $37,06 \%$ and $(1: 2)$ is $44,75 \%$ when they were compared with single furosemide. The result of spectral test and the changing of spectral profile explicit the hypothesis that there was an interaction between furosemide and $\beta$-cyclodextrin and in addition, the result of HyperChem molecular model analysis show that the inclusion complex has been made.
\end{abstract}

Key Words: Furosemide, $\beta$-cyclodextrin, inclusion complex , copresipitation, solid dispersion, dissolution. 